\title{
Legal Instruments Pertaining to Environmental Management in the Textile Sector of Bangladesh
}

\author{
Kamrul Islam 1,2,* \\ 1 Institute of Forestry and Enviornmental Sciences, University of Chittagong, Chittagong-4331, Bangladesh \\ 2 School of Engineering, Department of Systems Innovation, The University of Tokyo, 7-3-1 Hongo, Bunkyo-ku, \\ Tokyo 113-8656, Japan \\ * Correspondence: kamrul-islam@g.ecc.u-tokyo.ac.jp
}

\begin{abstract}
The aim of this short communication is to find out the legal set up that complies with the environmental management in the textile sector of Bangladesh. This sector is the one of the biggest contributor to the economy of the nation. This sector contributes $81 \%$ to the total export earnings involving an immense number of stakeholders to its production processes. It is also true that this sector is largely responsible for the overall environmental pollution through its effluent discharge. The findings suggest that there are both international and national legal guidelines exist for environmental management in the said sector. In order to improve the environmental standards rehearsing lawful instruments is compulsory for the said industries.
\end{abstract}

Keywords: environment; environmental pollution; environmental management; textile industry; legal instruments

\section{Introduction}

Although Bangladesh is an agrarian country but now it is being industrialized gradually. Its industrial sector is contributing to its national economy immensely [1]. Textile and clothing (T\&C) sector is the largest industrial sector of Bangladesh. This sector plays significant role in the national economy of Bangladesh which accounts for $40 \%$ of the total manufacturing and $50 \%$ of the industrial workforce. Textile and Ready Made Garments (RMG) started in the late 1970s and since then it has seen steady growth and now has become a top global exporter. About 15 billion USD export had been added in the year 2010 contributing $13 \%$ share of GDP of the country which has made this sector as the largest industrial one in the country. Textile industry has been making crucial contribution to rebuilding the country and its economy. This sector accounts for $81 \%$ of total export earnings of the country [1]. Figure 1 shows the focal statistics related to RMG exports of Bangladesh. The figure clearly indicates the significance of this industry to national economy.

Although Bangladesh is a resource hungry country, but proper management of its resources could help attaining better environment. It is a well-known fact that industrial activity causes serious environmental pollution [2-5]. Legal guidelines thus could control the nature of the pollution caused by the industries [6-9].

The main consumers of the textile products of Bangladesh are the European and North American countries. With the increasing demand, the buyers of that countries have set up some legal instruments considering the sustainability issues of environment. Again there are some national legal instruments which must be followed in the industrial set up for maintaining better environmental management [1]. 
Textile and clothing compliance indicates formulated guidelines and standards for the said industries. Though there may be a variety of compliance issue, but among them social and environmental compliance are most common. Social compliance is adopted to ensure better working environment, work days, freedom of association etc. while environmental compliance is formulated to ensure environmental laws to control pollution of water, air, land, and other resources as well [8].

The aim of this short communication is to identify and describe the legal guidelines that helps in better environmental management in the textile sector of Bangladesh. This approach will aid in quick assessment of the existing guidelines that pertains to textile sector of the country. Legal guidelines are divided into two segments: (1) International and (2) National. The most important guidelines are described in the subsequent sections of this study.

\section{International Legal Guidelines}

Social Accountability (SA) 800, Social Responsibility, Business Social Compliance Initiative (BSCI), WRAP (Worldwide Responsible for Apparel Production), Clean Cloth Campaign (CCC), Ethical Trade Initiative (ETI), Fairtrade, Fair Wear Foundation (FWF) are some examples of social compliance standards while ISO 14001, Oeko Tex Standard 1000 are examples of environmental standards. Some standards are formulated for T\&C industries to ensure sustainability, like GOTS (Global Organic Textile Standard), Bluesign, EU Flower etc.

The textile and garment industry is boosting its greener credentials through industry and supplier driven certifications and it ensures the safety of their supply chain. These certifications include Oeko Tex, Bluesign, EU Flower, and EcoLabel. Beside this, textile manufacturers are moving ahead with environmental initiatives targeted at energy efficiency, renewable energy use, waste recycling, sustainable resource use \& efficiency and other greener technologies adoption.

Oeko Tex Certification Body (USA) lists substances typically found in restricted substance lists (RSLs), as well as skin- sensitizing substances and has issued 73,000 certifications to manufacturers in more than 80 countries since its introduction in 1992. The Bluesign standard controls more than 6000 restricted or banned substances. The input stream management needs the advance testing of all components and processes engaged in the manufacturing of the product instead of only examining the manufacturers' final product.

The Ecological and Toxicological Association of Dyes and Organic Pigments Manufacturers (ETAD) member companies coordinate their efforts to minimize negative impacts of organic colorants on health and the environment. Member companies must abide by the ETAD Code of Ethics, based on the principles of responsible care, and they must also comply with all national and international chemical regulations.

Worldwide Responsible Accredited Production (WRAP) certifies complaint manufacturing and service facilities to a 12-point labor and environmental code. The program looks as RSLs as part of its certifications, especially as part of the new WRAPe program which evaluates chemical use, restricted chemicals, and REACH Compliance. Besides, Textile manufacturers also proactively look at their own facilities and production processes to minimize their environmental impact in party by tougher regulations.

The European EcoLabel is a voluntary scheme designed to encourage business to market products and services that are friendly to the environment. The 'flower' label is awarded only to those products with the 
least environmental impact in a product range, based on researches analyzing the impact of the product on the environment throughout its life-cycle, starting from raw material extraction in the pre-production stage, through production, distribution, and disposal.

Environmental problems associated with the textile processing are well known. Due to increasing global awareness regarding the issues of environmental pollution, improved environmental performances has become a major factor in the dynamics of the global market, and successful business around the world are striving to achieve the goals of responsible environmental behavior.

Enhancing sustainability in textile exports is essential to address the associated environmental problems on urgent basis. The new regime of international trade under World Trade Organization (WTO) requires that the production of textile products should comply local environmental standards. If these standards are not considered precisely, the textile products would not be accepted in the international markets.

The dynamic growth of the chemical industry has a huge impact on environment. Chemicals are the largest factor that have contributed to pollution and waste especially in textile and clothing sector. While pointing out that the roads to sustainability is tough, it is believed that a paradigm shift in approach towards sustainability is essential, and should be stressed on a more sustainable approach covering the life cycle of textile and clothing products.

\section{National Legal Guidelines}

Beside the international (western buyers) legal guidelines, there exists some national guidelines for environmental management in the textile sector of Bangladesh. These legal instruments act as a catalyst for improving the total quality of industrial environment in the textile sector of the country.

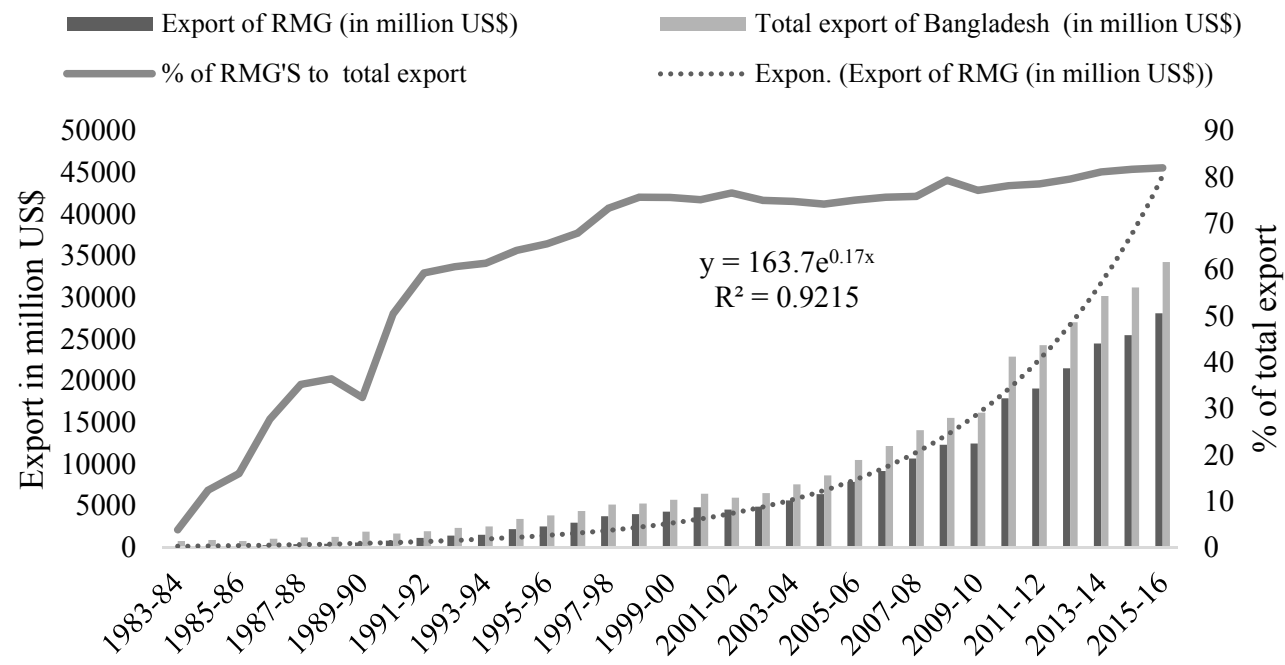

Fiscal year

Figure 1: RMG exports and its share to total export of Bangladesh 
The importance of environmental consideration, occupational health \& safety and land acquisition related to textile sector has been recognized in a number of national documents. The major relevant policies, acts, rules and plans are shown in Table 1.

Table 1: Legal instruments for environmental management in textile sector of Bangladesh

\begin{tabular}{cl}
\hline Category & \multicolumn{1}{c}{ Description of legal guidelines } \\
\hline Environment & (a) National Environmental Policy and Action Plan, 1992 \\
& (b) National Environmental Management and Action \\
& Plan (NEMAP), 1995 \\
& (c) Environmental Conservation Act (ECA), 1995 \\
Water Resources & (d) Environmental Conservation Rules, 1997 \\
& (e) Environmental Courts Act, 2000 \\
\hline Industrial, Occupational Health \& & (a) National Water Policy, 2010 \\
Safety and Construction & (b) National Water Management Plan, 2001 \\
& (a) Industrial Policy, 2016 \\
& (b) The Bangladesh Labor Act, 2006 \\
& (c) Bangladesh National Building Code, 2006 \\
\hline
\end{tabular}

Some of the major legal instruments are discussed in the following part of this study. These legal guidelines are directly or indirectly involved in the environmental management of textile sector of Bangladesh.

\subsection{National Environmental Policy and Action Plan, 1992}

The concept of environmental protection through national efforts was first declared with the adoption of the Environment Policy, 1992 and the Environment Action Plan, 1992. The importance of policies in beefing up the environmental regime is recognized in a number of international instruments including the World Conservation Strategy in 1980 and the Brundtland Commission Report, 1987. Paragraph 14 of Chapter 8 of Agenda 21 underscored the necessity of formulation of national policies as well as laws for environmental protection and sustainable development. The objectives of Environmental policy are to i) maintain ecological balance and overall development through protection and improvement of the environment; ii) protect the country against natural disaster; iii) identify and regulate activities, which pollute and degrade the environment; iv) ensure environmentally sound development in all sectors; v) ensure a sustainable, long term and environmentally sound base of natural resources; and vi) actively remain associate with all international environmental initiatives to the maximum possible extent.

Sector 2 of the said policy shows the guidelines for industry in broader aspect. The major clauses of it are:

2.1 Adoption of corrective measures by polluting industries in phases.

2.2 Undertake Environmental Impact Assessment (EIA) for all new industries both in public and private sectors.

2.3 Impose ban of establishment of industries producing goods, which cause environment pollution; close down such already existing industries in phases and discourage use of such polluting products through development/introduction of their environmentally sound substitutes.

2.4 Encourage development of environmentally sound and appropriate technology and initiatives on research and extension in the field of industry. Balance such initiatives with the best use of labor and provision of proper wages. 
2.5 Prevent wastage of raw materials in industries and ensure their sustainable use.

\subsection{National Environmental Management and Action Plan (NEMAP), 1995}

The National Environment Management Action Plan (NEMAP, 1995), based on a nationwide consultation program identified the main national environmental issues, including those related to the water sector which EA practitioners should note. The main related national concerns included damage from flood, river-bank erosion, environmental deterioration of water bodies, increased water pollution, shortage of irrigation water and drainage congestion; various specific regional concerns were also identified.

\subsection{Bangladesh Environment Conservation Act (ECA), 1995}

The Environmental Conservation Act (ECA) of 1995 is the main legislative framework document relating to environmental protection in Bangladesh. This act includes laws for conservation of the environment, improvement of environmental standards, and control and mitigation of environmental pollution. This act also established the Department of Environment (DoE), and empowers its Director General to take measures as she/he considers necessary which includes conducting inquiries, preventing probable accidents, advising the government, coordinating with other authorities or agencies, and collecting \& publicizing information about environmental pollution.

According to this act (Section 12), no industrial unit or project shall be established or undertaken without obtaining, in a manner prescribed by the accompanying rules, an Environmental Clearance Certificate (ECC) from the Director General of DoE.

\subsection{Bangladesh Environment Conservation Rules, 1997}

The Environment Conservation Rules, 1997 were issued by the Government of Bangladesh in exercise of the power conferred under the Environment Conservation Act (Section 20), 1995. The following aspects, among others, are covered under these rules: (i) declaration of ecologically critical areas (ii) classification of industries and projects into 4 categories (iii) procedures for issuing the Environmental Clearance Certificate (iv) determination of environmental standards.

These Rules were amended three times (17 February 2002, 26 August 2002 and 01 April 2003) to specify different sections like inclusion of Certificate of Fitness, Pollution Under Control Certificate, Fees for Environmental Clearance Certificate and other services etc. ECR'97 (Rule 7) classifies industrial units and projects into four categories depending on environmental impact and location for the purpose of issuance of ECC. These categories are:

(1) Green

(2) Orange (Amber) A

(3) Orange (Amber) B and

(4) Red

The ECR'97 also establishes the National Environmental Quality (EQS) for ambient air, various water sources/ bodies, industrial effluents, etc. Table 2 shows Industrial Project Effluent standard for Bangladesh.

The existing industrial units and projects and proposed industrial units and projects, which are considered to be low polluting are categorized under "green" and shall be granted environmental clearance. In case of proposed industrial units and projects falling in the orange- A, orange- B and red Categories, firstly a site clearance certificate and then an environmental clearance certificate will be issued. A broad description of those four categories of industries has been given in Schedule-1 of ECR'97. Beside the general requirements, for every orange- $\mathrm{B}$ and red category proposed industrial unit or project, the 
application must be accompanied with feasibility report on Initial Environmental Examination (IEE), Environmental Impact Assessment (EIA) based on approved ToR by DoE, Environmental Management Plan (EMP) etc.

Table 2: Bangladesh Standards for Industrial Project Effluent according to EQSB of DoE

\begin{tabular}{|c|c|c|c|c|}
\hline \multirow[t]{2}{*}{ Parameters } & \multirow[t]{2}{*}{ Unit } & \multicolumn{3}{|c|}{ Discharge to } \\
\hline & & $\begin{array}{l}\text { Inland Surface } \\
\text { Water }\end{array}$ & $\begin{array}{l}\text { Public Sewer from } \\
\text { Secondary } \\
\text { Treatment Plant }\end{array}$ & Irrigable land \\
\hline Ammonia Cal Nitrogen & $\mathrm{mg} / \mathrm{l}$ & 50 & 75 & 75 \\
\hline Ammonia & $\mathrm{mg} / \mathrm{l}$ & 5 & 5 & 15 \\
\hline Arsenic & $\mathrm{mg} / \mathrm{l}$ & 0.2 & 0.05 & 0.2 \\
\hline $\mathrm{BOD}_{5}$ & $\mathrm{mg} / \mathrm{l}$ & 50 & 250 & 100 \\
\hline Boron & $\mathrm{mg} / \mathrm{l}$ & 2 & 2 & 2 \\
\hline Cadmium & $\mathrm{mg} / \mathrm{l}$ & 0.05 & 0.5 & 0.5 \\
\hline Chloride & $\mathrm{mg} / \mathrm{l}$ & 600 & 600 & 600 \\
\hline Chromium (total Cr) & $\mathrm{mg} / \mathrm{l}$ & 0.5 & 1 & 1 \\
\hline COD & $\mathrm{mg} / \mathrm{l}$ & 200 & 400 & 400 \\
\hline Chromium (hexavalent) & $\mathrm{mg} / \mathrm{l}$ & 0.5 & 1 & 1 \\
\hline Copper & $\mathrm{mg} / \mathrm{l}$ & 0.5 & 3 & 3 \\
\hline Dissolved Oxygen & $\mathrm{mg} / \mathrm{l}$ & $4.5-8$ & $4.5-8$ & $4.5-8$ \\
\hline Electro-conductivity & $\mu \mathrm{mohms} / \mathrm{cm}$ & 1200 & 1200 & 1200 \\
\hline Total dissolved solids & $\mathrm{mg} / \mathrm{l}$ & 2100 & 2100 & 2100 \\
\hline Fluoride & $\mathrm{mg} / \mathrm{l}$ & 2 & 15 & 10 \\
\hline Sulfide & $\mathrm{mg} / \mathrm{l}$ & 1 & 2 & 2 \\
\hline Iron & $\mathrm{mg} / \mathrm{l}$ & 2 & 2 & 2 \\
\hline Kjeldahl nitrogen & $\mathrm{mg} / \mathrm{l}$ & 100 & 100 & 100 \\
\hline Lead & $\mathrm{mg} / \mathrm{l}$ & 0.1 & 1 & 0.1 \\
\hline Manganese & $\mathrm{mg} / \mathrm{l}$ & 5 & 5 & 5 \\
\hline Mercury & $\mathrm{mg} / \mathrm{l}$ & 0.01 & 0.01 & 0.01 \\
\hline Nickel & $\mathrm{mg} / \mathrm{l}$ & 1 & 2 & 1 \\
\hline Nitrate & $\mathrm{mg} / \mathrm{l}$ & 10 & Not set & 10 \\
\hline Oil and grease & $\mathrm{mg} / \mathrm{l}$ & 10 & 20 & 10 \\
\hline Phenolic compounds & $\mathrm{mg} / \mathrm{l}$ & 1 & 5 & 1 \\
\hline Dissolved phosphorous & $\mathrm{mg} / \mathrm{l}$ & 8 & 8 & 15 \\
\hline Radioactive substance & \multicolumn{4}{|c|}{ (to be specified by Bangladesh Atomic Energy Commission) } \\
\hline $\mathrm{pH}$ & & $6-9$ & $6-9$ & $6-9$ \\
\hline Selenium & $\mathrm{mg} / \mathrm{l}$ & 0.05 & 0.05 & 0.05 \\
\hline Zinc & $\mathrm{mg} / \mathrm{l}$ & 5 & 10 & 10 \\
\hline Total dissolved solids & $\mathrm{mg} / \mathrm{l}$ & 2100 & 2100 & 2100 \\
\hline \multirow[t]{2}{*}{ Temperature } & 'C (summer) & 40 & 40 & 40 \\
\hline & C (winter) & 45 & 45 & 45 \\
\hline Suspended solids & $\mathrm{mg} / \mathrm{l}$ & 150 & 500 & 200 \\
\hline Cyanide & $\mathrm{mg} / \mathrm{l}$ & 0.1 & 2 & 0.2 \\
\hline
\end{tabular}

The ECR'97 also contains the guidelines for obtaining Environmental Clearance Certificates (ECC) from the DoE for different types of proposed units or projects. Any organization or person wishing to 
establish an industrial unit or project must obtain ECC from the Director General. The application for such certificate must be in the prescribed format together with the prescribed fees laid down in Schedule 13, through the deposit of a Treasury Chalan (Pay Order) in favor of the Director General. Rule 8 prescribes the maximum duration of validity of such certificate ( 3 years for green category and 1 year for other categories) and compulsory requirement renewal of certificate at least 30 days before expiry of its validity.

\subsection{National Industrial Policy, 2016}

Chapter 14 of the national industrial policy, 2016 describes about the environment friendly industrial management. The clauses are as below:

i. Decision will be made for allocation of soil and water resources to industrial project after EIA.

ii. Awareness will be created to establish ETP, CETP in order to control pollution by industries.

iii. The industries which take measures against adverse impact of climate change will be brought under Clean Development Mechanism (CDM) and government will cooperate in this issue.

iv. Industrial establishment will be given priority based on disaster risk reduction and surrounding environment.

v. National and international investors' will be given incentives for the waste management industry establishment.

vi. Business organizations, NGOs, and other social organizations will be encouraged to participate actively in industrial waste management and environmental conservation activities.

vii. It will be encouraged to establish green industry and industry capable of climate change mitigation.

viii. It will be discouraged to establish industry in intensive cultivable and more fertile land.

ix. Investment in environment friendly big project through public private partnership will be encouraged.

x. Industrial entrepreneurs will be encouraged to follow 3R (Reduce, Reuse, and Recycle) strategy in case of industrial establishment and management.

\section{Conclusion}

As a developing country, Bangladesh is under close scrutiny of international investors, buyers, NGOs and corporate social responsibility (CSR) stakeholders regarding compliance in textile sector. The above mentioned guidelines exist for the environmental management in the textile sector of Bangladesh and new guidelines are added along with the correction of existing ones every year. This will ensure best management practices in this sector in the coming years. But the important thing here to be noted is the adoption and exercising practically. Awareness regarding it is a must for the betterment of the scenarios.

\section{References}

[1] A. Berg, S. Hedrich, H. Kempf, T. Tochtermann, Bangladesh's ready-made garments landscape: The challenge of growth. Apparel, Fash. Lux. Pract. (2011) 24.

[2] K. Islam, M. Jashimuddin, B. Nath, T.K. Nath, Quantitative Assessment of Land Cover Change Using Landsat Time Series Data: Case of Chunati Wildlife Sanctuary (CWS), Bangladesh. Int. J. Environ. Geoinformatics 3 (2016) 45-55.

[3] K. Islam, S.C. Majumder, Economic evaluation of Foy's lake, Chittagong using travel cost method. Indian J. Econ. Dev. 3 (2015) 1-6. 
[4] K. Islam, S.C. Majumder, Status of Industrial Noise Levels and its Impact on Workers' Health: A Case Study of Kalurghat Heavy Industrial Area in Bangladesh. Dev. Res. Work. Pap. Ser. 29 (2015) $1-11$.

[5] F.M. Rahman, K. Islam, N.K. Islam, Industrial Symbiosis: A Review on Uncovering Approaches, Opportunities, Barriers and Policies. J. Civ. Eng. Environ. Sci. 2 (2016) 011-019.

[6] A. Malik, R. Akhtar, E. Grohmann, Environ. Deterior. Hum. Heal. Nat. Anthropog. Determ. (2014) 1-421.

[7] M. Islam, M. Khan, Environmental Sustainability Evaluation of Apparel Product: A Case Study on Knitted T-Shirt. J. Text. 2014 (2014).

[8] S.S. Muthu, Assess. Environ. Impact Text. Cloth. Supply Chain (2014) 180-186.

[9] S. You, S. Cheng, H. Yan, The impact of textile industry on China's environment. Int. J. Fash. Des. Technol. Educ. 2 (2009) 33-43. 